\title{
PENGARUH PERBANDINGAN SARI BUAH MENGKUDU (Morinda citrifolia L) DAN FILTRAT DAUN RAMBUTAN (Nephelium lappaceum L) TERHADAP KARAKTERISTIK MINUMAN FUNGSIONAL
}

\author{
Yudi Garnida \\ Hasnelly \\ Program Studi Teknologi Pangan, Fakultas Teknik, Universitas Pasundan, Jl. Dr.Setiabudi No 93, Bandung, 40153, \\ Indonesia \\ Email : yudigarnida@unpas.ac.id
}

\begin{abstract}
Abstrak
Tujuan dari penelitian adalah untuk mempelajari pengaruh perbandingan Sari Buah Mengkudu (Morinda citrifolia L) dan filtrat Daun Rambutan (Naphelium lappaceum L) terhadap karakteristik pada minuman fungsional. Manfaat penelitian ini adalah untuk memberikan informasi dan pengetahuan terhadap dunia penelitian, pendidikan, dan masyarakat mengenai proses pemanfaatan sumber pangan lokal yang dapat dijadikan sebagai minuman fungsional menjadi suatu produk yang bermanfaat bagi kesehatan. Penelitian ini menggunakan Rancangan Acak Kelompok (RAK) yang terdiri dari perbandingan sari buah mengkudu, filtrat daun rambutan, pemanis dan penstabil yang terdiri dari 6 taraf. Variabel percobaan terdiri dari 1 faktor yaitu pengaruh perbandingan sari buah mengkudu : filtrat daun rambutan yang terdiri dari 6 taraf yaitu $: \mathrm{m} 1=4: 1, \mathrm{~m} 2=3: 1, \mathrm{~m} 3=2: 1, \mathrm{~m} 4=1: 1, \mathrm{~m} 5=1: 2, \mathrm{~m} 6=1: 3$. Rancangan respon yang dilakukan pada penelitian ini adalah uji organoleptik dan pengukuran aktivitas antioksidan, kadar Tanin, dan analisis kadar vitamin C. Hasil penelitian pendahuluan yaitu didapatkan hasil bahwa konsentrasi penambahan gula stevia yang disukai oleh kebanyakan panelis pada uji hedonik tidak berpengaruh nyata, sehingga konsentrasi yang digunakan pada penelitian utama adalah konsentrasi yang paling efisien yaitu $1 \%$. Hasil penelitian pendahuluan aktivitas antioksidan yaitu didapatkan hasil bahwa aktivitas antioksidan yang terbaik terdapat pada buah mengkudu dengan nilai IC $_{50}$ yaitu 1979,246, nilai IC50 pada sari buah mengkudu pasca fermentasi adalah 1123,1076 ppm. Pada penelitian utama analisis antioksidan produk terpilih adalah nilai IC50 pada sari buah mengkudu yaitu 1523,308 ppm. Hasil penelitian pendahuluan terhadap kadar Tanin pada daun rambutan adalah $0,0347 \%$ dan hasil penelitian utama terhadap kadar Tanin pada produk terpilih adalah 0,0657\%. Hasil penelitian utama terhadap analisis kadar vitamin C, dapat disimpulkan bahwa pengaruh perbandingan sari buah mengkudu : filtrat daun rambutan tidak berpengaruh nyata. Berdasarkan uji hedonik pada penelitian utama didapatkan produk terbaik yaitu perbandingan sari buah mengkudu : filtrat daun rambutan yaitu $1: 3$.
\end{abstract}

\begin{abstract}
The purpose of the research was to study the influence of comparison of Juice Noni (Morinda citrifolia 1.) and the filtrate Rambutan Leaves (Naphelium lappaceum 1.) against characteristics on functional drinks. The benefits of this research was to provide information and knowledge of the world of research, education, and the public about the process of utilization of local food sources that can serve as a functional beverage into a product beneficial to health. The experiment is use a random Design Group (RDG) which consists of the comparison of filtrate is noni fruit, rambutan, and sweetener leaves stabilizers consisting of 6 levels. The experiment consists of 1 variable factors, namely the influence of noni fruit juice: comparison of filtrate leaves rambutan that consists of 6 levels namely: $\mathrm{m} 1=$ $4: 1, \mathrm{~m} 2=3: 1, \mathrm{~m} 3=2: 1, \mathrm{~m} 4=1: 1, \mathrm{~m} 5=1: 2, \mathrm{~m} 6=1: 3$. The draft of the response made on the research was using organoleptic test and measurement of antioxidant activities, levels of Tannins, and an analysis of the levels of vitamin C. Preliminary research results that is obtained as a result of the addition of stevia sugar concentrations that are favored by most panelists at hedonik do not affect the real test, so the concentration used in the main tudy is the concentration most efficient i.e. 3\%. Preliminary research results antioxidant activity that is obtained as a result ofthat there are the best antioxidant activity in fruit of noni with IC50 values is 1979,246 on juice post fermentation was $1123,1076 \mathrm{ppm}$ Primary analysis on the research of the selected product is an antioxidant value of noni juice at IC50 that is $1523.308 \mathrm{ppm}$. Preliminary research results towards the levels of Tannin in the leaves of rambutan is $0.0347 \%$ and the main research results towards the levels of Tannins on the selected product is $0.0657 \%$. The main research results towards the analysis of the levels of vitamin $\mathrm{C}$, it can be concluded that the influence of the ration between noni fruit juice and filtrate leaves of rambutan has no effect. Based on a test of hedonic on the primary research obtained the best products was the ratio of filtrate leaves rambutan and noni fruit juice that is 1:3.
\end{abstract}

Keywords: Noni, Rambutan, Functional Drinks Leaf, Stevia Sugar 


\section{Pendahuluan}

Indonesia memiliki sumber pangan lokal yang melimpah dan beranekaragam yang sangat berpotensi untuk dikembangkan. Perkembangan ilmu teknologi saat ini memungkinkan untuk dapat mengolah pangan menjadi berbagai macam produk pangan baru yang memiliki nilai gizi dan baik untuk kesehatan.

Dewasa ini, terutama di negara-negara maju, terdapat kecenderungan konsumen dalam mengonsumsi suatu makanan atau minuman, tidak hanya menilai dari segi kandungan zat gizinya serta lezat atau tidaknya suatu produk, tetapi juga mempertimbangkan segi pengaruh makanan tersebut pada kesehatan tubuhnya. Oleh karena itu, nampaknya kini fungsi pangan tidak hanya dua macam tetapi tiga macam. Setelah fungsinya sebagai penyuplai zat-zat gizi bagi tubuh dan pemuas mulut dengan citarasanya, pangan juga dituntut untuk berfungsi menjaga kesehatan dan kebugaran tubuh, atau menurunkan efek negatif dari suatu penyakit tertentu, dan bahkan kalau mungkin dapat menyembuhkan penyakit tersebut. Dengan demikian pangan tidak hanya harus bernilai gizi tinggi dan enak citarasanya, tetapi juga bersifat fungsional bagi tubuh. Makanan atau minuman dikatakan mempunyai sifat fungsional bila mengandung senyawa (zat gizi atau non-gizi) yang dapat mempengaruhi satu atau sejumlah tertentu fungsi fisiologis dalam tubuh, tetapi yang bersifat positif, sehingga dapat memenuhi kriteria fungsional atau menyehatkan (Muchtadi, 2012).

Pangan fungsional adalah pangan yang secara alami maupun melalui proses mengandung satu atau lebih senyawa yang berdasarkan hasil kajian ilmiah dianggap mempunyai fungsi-fungsi fisiologis tertentu yang bermanfaat bagi kesehatan. Pangan fungsional dikonsumsi layaknya makanan atau minuman, mempunyai karakteristik sensori berupa penampakan warna, tekstur dan cita rasa yang dapat diterima oleh konsumen, serta tidak memberikan kontraindikasi dan tidak memberikan efek samping terhadap metabolisme zat gizi lainnya jika digunakan pada jumlah penggunaan yang dianjurkan. Meskipun mengandung senyawa yang bermanfaat bagi kesehatan, pangan fungsional tidak berbentuk kapsul, tablet atau bubuk yang berasal dari senyawa alami (Badan Pengawasan Obat dan Makanan, 2001).

Minuman fungsional adalah salah satu produk makanan fungsional yang banyak dihasilkan industri pangan. Melalui minuman, komponen-komponen fungsional dapat dengan mudah diformulasikan serta dapat digunakan dengan cepat oleh tubuh setelah dikonsumsi. Meskipun demikian, hanya komponenkomponen yang kelarutannya tinggi atau dapat didispersikan secara merata yang dapat diformulasikan ke dalam minuman fungsional (Winarti, 2010).

Tanaman mengkudu (Morinda citrifolia L.) mendapat perhatian sangat besar karena adanya fakta empiris serta bukti penelitian ilmiah yang menyatakan bahwa buah mengkudu berkhasiat untuk mengobati beberapa penyakit degeneratif seperti kanker, tumor, dan diabetes. Hal tersebut membuat produk olahan buah mengkudu diproduksi secara luas dalam berbagai merek dengan klaim dapat mengobati berbagai jenis penyakit seperti tekanan darah tinggi, radang ginjal, radang empedu, disentri, liver, diabetes, cacingan, artistis, atherosklerosis, sakit perut, dan masuk angin. Dengan adanya fakta-fakta tersebut maka mengkudu berpotensi dikembangkan sebagai pangan fungsional (Pohan dan Antara, 2001)

Buah mengkudu mengandung berbagai senyawa yang penting bagi kesehatan. Hasil penelitian membuktikan bahwa buah mengkudu mengandung senyawa metabolit sekunder yang sangat bermanfaat bagi kesehatan, selain kandungan nutrisinya yang juga beragam seperti vitamin $\mathrm{A}, \mathrm{C}$, niasin, tiamin dan riboflavin, serta mineral seperti zat besi, kalsium, natrium, dan kalium (Winarti, 2005).

Rambutan dengan nama latin Naphelium lappaceum $\mathrm{L}$ sudah banyak dikenal masyarakat sebagai buah-buahan yang cukup digemari. Daging buah rambutan berwarna putih transparan, tumbuh menyelimuti biji. Rambutan tidak hanya digunakan dalam bentuk segar saja, namun dapat digunakan sebagai obat. Kandungan kimia dalam buah rambutan adalah karbohidrat, protein, lemak, fosfor, besi, kalsium dan vitamin C. Selain pada buahnya, kulit buah, biji, daun dan kulit batang juga dapat digunakan sebagai obat. Pada kulit buah dan daun mengandung tanin, dan saponin, pada biji mengandung saponin dan polifenol, sedangkan pada kulit batang mengandung tanin, saponin, flavonoida, pectric subtances dan zat besi (Septiatin, 2009).

Khasiat dari tanaman rambutan yang digunakan sebagai pengobatan, seperti kulit buah digunakan untuk mengatasi disentri dan demam. Kulit kayu digunakan untuk mengatasi sariawan. Daun digunakan untuk mengatasi diare dan menghitamkan rambut. Akar digunakan untuk mengatasi demam. Biji digunakan untuk kencing manis (Septiatin, 2009).

Salah satu bagian dari tanaman rambutan yang dapat berguna untuk kesehatan adalah daun rambutan. Daun rambutan mengandung tanin dan saponin (Dalimartha, 2007). Tanin merupakan kelompok besar dari senyawa kompleks yang didistribusikan merata pada berbagai tanaman. Hampir setiap famili tanaman mempunyai spesies yang mengandung tanin. Tanin biasanya terdapat pada bagian tanaman yang spesifik seperti daun, buah, kulit dahan dan batang. Tanin adalah polifenol tanaman yang berfungsi mengikat dan mengendapkan protein. Tanin juga dipakai untuk menyamak kulit (Harborne, 1987). Dalam dunia pengobatan, tanin berfungsi untuk mengobati diare, menghentikan pendarahan, dan mengobati ambeien (Andriyani dkk, 2010). 
Berdasarkan uraian latar belakang di atas, masalah yang dapat diidentifikasi untuk penelitian yaitu apakah perbandingan Sari Buah Mengkudu (Morinda citrifolia L) dan filtrat Daun Rambutan (Naphelium lappaceum $L$ ) dapat berpengaruh terhadap karakteristik minuman fungsional

Maksud dari penelitian ini adalah untuk memanfaatkan Sari Buah Mengkudu (Morinda citrifolia L) dan filtrat Daun Rambutan (Naphelium lappaceum L) menjadi suatu bentuk olahan pangan fungsional yang praktis dan bermanfaat bagi kesehatan dengan pembuatan minuman fungsional.

Tujuan dari penelitian adalah untuk mempelajari pengaruh perbandingan Sari Buah Mengkudu (Morinda citrifolia L) dan filtrat Daun Rambutan (Naphelium lappaceum L) terhadap karakteristik pada minuman fungsional.

Manfaat penelitian ini adalah untuk memberikan informasi dan pengetahuan terhadap dunia penelitian, pendidikan, dan masyarakat mengenai proses pemanfaatan sumber pangan lokal yang dapat dijadikan sebagai minuman fungsional menjadi suatu produk yang bermanfaat bagi kesehatan.

Buah mengkudu mengandung berbagai senyawa yang penting bagi kesehatan. Hasil penelitian membuktikan bahwa buah mengkudu mengandung senyawa metabolit sekunder yang sangat bermanfaat bagi kesehatan, selain kandungan nutrisinya yang juga beragam seperti vitamin $\mathrm{A}, \mathrm{C}$, niasin, tiamin dan riboflavin, serta mineral seperti zat besi, kalsium, natrium, dan kalium (Winarti, 2005).

Beberapa jenis senyawa fitokimia dalam buah mengkudu adalah terpen, acubin, lasperuloside, alizarin, zat-zat antrakuinon, asam askorbat, asam kaproat, asam kaprilat, zat-zat skopoletin, damnakantal, dan alkaloid (Anon 1997 dalam Pohan dan Antara 2001). Senyawa turunan antrakuinon dalam mengkudu antara lain adalah morindin, morindon, dan alizarin, sedangkan alkaloidnya antara lain xeronin dan proxeronin (precursor xeronin). Xeronin merupakan alkaloid yang dibutuhkan tubuh manusia untuk mengaktifkan enzim serta mengatur dan membentuk struktur protein (Solomon, 1998).

Salah satu bagian dari tanaman rambutan yang dapat berguna untuk kesehatan adalah daun rambutan. Daun rambutan mengandung tanin dan saponin (Dalimartha, 2007). Tanin merupakan kelompok besar dari senyawa kompleks yang didistribusikan merata pada berbagai tanaman. Hampir setiap famili tanaman mempunyai spesies yang mengandung tanin. Tanin biasanya terdapat pada bagian tanaman yang spesifik seperti daun, buah, kulit dahan dan batang. Tanin adalah polifenol tanaman yang berfungsi mengikat dan mengendapkan protein. Tanin juga dipakai untuk menyamak kulit (Harborne, 1987). Dalam dunia pengobatan, tanin berfungsi untuk mengobati diare, menghentikan pendarahan, dan mengobati ambeien (Andriyani dkk, 2010).
Kandungan pada daun rambutan dapat digunakan untuk menurunkan demam, bahan yang digunakan sama halnya dengan penurunan demam dengan menggunakan kulit buah rambutan.

Bahan yang diperlukan 15 gr kulit buah rambutan dan 3 gelas air. Cara meracik kulit buah rambutan yang telah dikeringkan kemudian dicuci sampai bersih, dan direbus sampai mendidih selama 15 menit, setelah dingin kemudian disaring. Cara pemakaian airnya diminum 3 kali sehari, masingmasing 1/3 bagian (Septiatin, 2009).

Proses pembuatan sari buah terdapat masalahmasalah yang dapat terjadi yaitu masalah cita rasa, aroma, warna dari sari buah dan stabilitas cairan selama penyimpanan. Kekurangan dari minuman fungsional yaitu mudah terjadinya ketidakstabilan cairan sehingga penampakannya kurang menarik. Menurut Widjanarko (1996), selain aroma dan rasa, salah satu penentuan kualitas sari buah adalah penampakannya.

Hasil penelitian yang dilakukan Tezar dkk (2008) menunjukkan bahwa penambahan stevia pada sari buah dengan sukrosa $6 \%$ tidak bisa menyamai tingkat kemanisan sukrosa $10 \%$ sebagai standar rasa yang pas dari sari buah belimbing manis. Namun konsentrasi penambahan $4 \%$ stevia berbeda nyata dengan konsentrasi $2 \%$ dan $1 \%$. Hal ini menunjukkan kecenderungan bahwa semakin tinggi konsentrasi stevia yang ditambahkan mengkibatkan semakin tingginya tingkat kemanisan yang dihasilkan. Namun penambahan tidak diteruskan melebihi $4 \%$ karena berdasarkan deteksi aftertaste, rasa sepat pada konsentrasi $4 \%$ saja sudah sangat mengganggu rasa dari sari buah belimbing. Bahkan pada konsentrasi ekstrak stevia terendah pun aftertaste pahit sudah terasa.

Serbuk stevia pada produk minuman teh hijau berkisar antara 0,05\% hingga 6\% (Shelzer, 2004). Pembuatan minuman fungsional jelli kulit buah naga merah dan rosella menggunakan serbuk stevia sebanyak dua gram dari total bahan $200 \mathrm{~mL}$ (Karismawati, 2015).

Penelitian ini menggunakan waktu pemanasan selama 10 menit. Menurut Harismah dkk (2014) dalam penelitiannya mengenai sirup rosela dengan pemanis daun stevia menjelaskan bahwa pemanasan kelopak bunga rosella selama 10 menit sudah cukup mengeluarkan semua zat warna dari kelopak bunga rosella.

Penelitian ini akan digunakan suhu pemanasan sebesar $70^{\circ} \mathrm{C}$.

Menurut Tanggara (2013) dalam penelitiannya mengenai sirup gojiberry dengan kombinasi kadar angkak dan suhu pemanasan menunjukkan hasil bahwa Sirup gojiberry kombinasi suhu pemanasan $70^{\circ} \mathrm{C}$ dan kadar angkak $0,30 \%$ memiliki kualitas paling baik ditinjau dari kadar gula reduksi, sukrosa, coliform, dan organoleptik (warna, aroma, rasa, dan kekentalan).

Kerangka pemikiran di atas, maka dapat diperoleh hipotesis yaitu diduga adanya pengaruh perbandingan Sari Buah Mengkudu (Morinda citrifolia L) dan Daun 
Rambutan (Naphelium lappaceum L) terhadap karakteristik minuman fungsional.

\section{Bahan dan Metode Penelitian}

Bahan baku utama yang digunakan dalam penelitian ini adalah buah mengkudu (Morinda citrifolia) yang diperoleh dari daerah Kiaracondong Bandung, daun rambutan (Nephelium lappaceum L.) yang diperoleh dari daerah Kiaracondong Bandung, pemanis alami gula stevia yang diperoleh dari Setiabudhi Supermarket Bandung, gula merah yang diperoleh dari pasar tradisional Kiaracondong dan air.

Bahan-bahan yang digunakan untuk analisis kimia yaitu aquadest, $\mathrm{HCl} 4 \mathrm{~N}, \mathrm{~Pb}$ asetat $5 \%, \mathrm{Na}-$ posphat, $\mathrm{NaOH} 4 \mathrm{~N}$, larutan luff schroorl, KI 30\%, $\mathrm{H}_{2} \mathrm{SO}_{4} 6 \mathrm{~N}, \mathrm{Na}_{2} \mathrm{~S}_{2} \mathrm{O}_{3} 0,1 \mathrm{~N}$, amilum, iod $0,05 \mathrm{~N}$, indikator kanji, larutan $\mathrm{DPPH}$, larutan indigo, $\mathrm{KMnO}_{4}$, dan $\mathrm{NaCl}$.

\section{Penelitian Pendahuluan}

Penelitian pendahuluan dilaksanakan untuk mengetahui konsentrasi pemanis gula stevia dimana hasil penentuan konsentrasi ditentukan dari skor tertinggi yang diberikan oleh 30 orang panelis pada saat uji organoleptik. Penentuan konsentrasi pemanis dilakukan dengan perbandingan sari buah mengkudu : filtrat daun rambutan, yaitu $1: 1$ dengan konsentrasi pemanis sebagai berikut : $\mathrm{p} 1=1 \%, \mathrm{p} 2=2 \%, \mathrm{p} 3=3 \%$, p4 $=4 \%$. Penelitian pendahuluan dilakukan pula analisis kimia untuk mengetahui kandungan aktivitas antioksidan dengan metode DPPH (AOAC, 2012) terhadap sari buah mengkudu dan analisis kadar tanin terhadap filtrat daun rambutan.

\section{Penelitian Utama}

Penelitian utama dilaksanakan untuk menentukan perbandingan terbaik dari sari buah mengkudu dan filtrat daun rambutan. Penelitian utama mencakup rancangan perlakuan, rancangan percobaan, rancangan respon, dan rancangan analisis.

Rancangan perlakuan pada penelitian terdiri dari satu faktor, yaitu faktor perbandingan sari buah mengkudu dengan filtrat daun rambutan (M) yang terdiri dari 6 taraf, yaitu:

$\mathrm{m} 1=4: 1$ (Mengkudu : Rambutan)

$\mathrm{m} 2=3: 1$ (Mengkudu : Rambutan)

m3 = $2: 1$ (Mengkudu : Rambutan)

m4 = 1: 1 (Mengkudu : Rambutan)

m5 = $1: 2$ (Mengkudu : Rambutan)

m6 = $1: 3$ (Mengkudu : Rambutan)

Rancangan percobaan yang digunakan pada penelitian ini adalah Rancangan Acak Kelompok (RAK) dengan 4 kali pengulangan sehingga diperoleh 24 kali perlakuan.

Rancangan respon dalam penelitian ini meliputi respon kimia yaitu analisis analisis vitamin C. Respon organoleptik yang dilakukan pada penelitian ini adalah penilaian terhadap warna, rasa, aroma, dan aftertaste.
Respon terpilih yang dilakukan pada penelitian ini adalah analisis aktivitas antioksidan metode DPPH (AOAC, 2012) serta analisis kadar tannin pada produk terpilih. Penentuan produk terpilih yaitu berdasarkan uji hedonik.

\section{Prosedur Penelitian}

Penelitian Pendahuluan

Pada penelitian pendahuluan dilakukan pengujian bahan baku meliputi analisis kadar tannin daun rambutan dan aktivitas antioksidan dengan metode DPPH terhadap buah mengkudu. Penelitian pendahuluan dilakukan pula penentuan kadar pemanis dengan metode uji hedonik.

Prosedur penelitian penambahan pemanis minuman fungsional sari buah mengkudu dan filtrat daun rambutan yang dilakukan pada penelitian ini adalah sebagai berikut :

1. Persiapan bahan

Buah mengkudu dan daun rambutan disiapkan untuk dilakukan proses selanjutnya.

2. Penimbangan

Penimbangan merupakan proses persiapan bahan baku sebelum dilakukan proses selanjutnya. Untuk buah mengkudu ditimbang seberat $2 \mathrm{~kg}$ dan daun rambutan ditimbang seberat 75 gram.

3. Pencucian

Bahan yang sudah siap, dicuci pada air yang mengalir untuk membersihkan kotoran berupa tanah atau debu yang menempel. Dalam pencucian diusahakan agar kotoran tidak mempengaruhi warna penampakan bahan baku, karena dikhawatirkan kotoran yang terbawa akan mempengaruhi khasiat dan rasa minuman fungsional nantinya.

\section{Size Reduction}

Size Reduction atau memperkecil ukuran dari bahan dilakukan dengan tujuan mempermudah proses penghancuran. Reduksi ukuran hanya dilakukan pada buah mengkudu.

5. Penghancuran

Proses penghancuran dilakukan dengan menggunakan blender dengan tujuan untuk mendapatkan sari buah mengkudu. Proses penghancuran hanya dilakukan pada buah mengkudu.

6. Fermentasi

Sari buah mengkudu yang didapatkan dari hasil penghancuran kemudian dilakukan fermentasi dengan tujuan mengurangi sampai menghilangkan bau dari buah mengkudu dengan menambahkan 10 gr gula merah untuk setiap liter sari buah mengkudu, kemudian menyimpannya dalam suhu kamar $\left(25^{\circ} \mathrm{C}\right)$ selama 2-7 hari (Bangun, 2002).

7. Perebusan

Perebusan dilakukan pada daun rambutan selama 10 menit dengan suhu $70^{\circ} \mathrm{C}$, perebusan dilakukan untuk mendapatkan filtrat dari daun rambutan dimana dilakukan proses penambahan air dan perebusan dilakukan sampai berat air mencapai 1/3 dari berat awal. 


\section{Penyaringan}

Proses penyaringan pada daun rambutan merupakan proses memisahkan antara daun rambutan dan filtrat yang akan digunakan untuk proses pencampuran. Pada buah mengkudu dilakukan proses penyaringan untuk memisahkan sari buah mengkudu dengan ampas buah mengkudu.

9. Pencampuran I

Proses pencampuran berupa pencampuran sari buah mengkudu dan filtrat daun rambutan. Pencampuran I di penelitian pendahuluan penentuan konsentrasi pemanis dilakukan dengan perbandingan sari buah mengkudu : filtrat daun rambutan yaitu $1: 1$. 10. Pencampuran II

Proses pencampuran II berupa penambahan konsentrasi pemanis, yaitu sebagai berikut : $\mathrm{p} 1=1 \%, \mathrm{p} 2$ $=2 \%, \mathrm{p} 3=3 \%$, dan $\mathrm{p} 4=4 \%$.

\section{Pengemasan}

Proses pengemasan merupakan proses selanjutnya dimana produk di kemas dengan botol kaca yang sudah di sterilisasi dahulu.

\section{Penelitian Utama}

Pada penelitian utama yang dilakukan yaitu proses pembuatan minuman fungsional sari buah mengkudu dan filtrat daun rambutan untuk mengetahui pengaruh perbandingan sari buah mengkudu dan filtrat daun rambutan terhadap karakterisitik minuman fungsional.

Prosedur penelitian utama minuman fungsional sari buah mengkudu dan filtrat daun rambutan yang dilakukan pada penelitian ini adalah sebagai berikut :

1. Persiapan bahan

Buah mengkudu dan daun rambutan disiapkan untuk dilakukan proses selanjutnya.

2. Penimbangan

Penimbangan merupakan proses persiapan bahan baku sebelum dilakukan proses selanjutnya. Untuk buah mengkudu ditimbang seberat $3,3 \mathrm{~kg}$ dan daun rambutan ditimbang seberat 90 gram.

3. Pencucian

Bahan yang sudah siap, dicuci pada air yang mengalir untuk membersihkan kotoran berupa tanah atau debu yang menempel. Dalam pencucian diusahakan agar kotoran tidak mempengaruhi warna penampakan bahan baku, karena dikhawatirkan kotoran yang terbawa akan mempengaruhi khasiat dan rasa minuman fungsional nantinya.

\section{Size Reduction}

Size Reduction atau memperkecil ukuran dari bahan dilakukan dengan tujuan mempermudah proses penghancuran. Reduksi ukuran hanya dilakukan pada buah mengkudu.

\section{Penghancuran}

Proses penghancuran dilakukan dengan menggunakan blender dengan tujuan untuk mendapatkan sari buah mengkudu. Proses penghancuran hanya dilakukan pada buah mengkudu.

\section{Fermentasi}

Sari buah mengkudu yang didapatkan dari hasil penghancuran kemudian dilakukan fermentasi dengan tujuan mengurangi sampai menghilangkan bau dari buah mengkudu dengan menambahkan 10 gr gula merah untuk setiap liter sari buah mengkudu, kemudian menyimpannya dalam suhu kamar $\left(25^{\circ} \mathrm{C}\right)$ selama 2-7 hari (Bangun, 2002).

\section{Perebusan}

Perebusan dilakukan pada daun rambutan selama 15 menit dengan suhu $70^{\circ} \mathrm{C}$, perebusan dilakukan untuk mendapatkan filtrat dari daun rambutan dimana dilakukan proses penambahan air dan perebusan dilakukan sampai berat air mencapai 1/3 dari berat awal. 8. Penyaringan

Proses penyaringan pada daun rambutan merupakan proses memisahkan antara daun rambutan dan filtrat yang akan digunakan untuk proses pencampuran. Pada buah mengkudu dilakukan proses penyaringan untuk memisahkan sari buah mengkudu dengan ampas buah mengkudu.

9. Pencampuran I

Proses pencampuran berupa pencampuran sari buah mengkudu dan filtrat daun rambutan. Pencampuran I di penelitian pendahuluan penentuan konsentrasi dilakukan dengan perbandingan sari buah mengkudu : filtrat daun rambutan, yaitu: $\mathrm{m} 1=4: 1, \mathrm{~m} 2$ $=3: 1, \mathrm{~m} 3=2: 1, \mathrm{~m} 4=1: 1, \mathrm{~m} 5=1: 2, \mathrm{~m} 6=1: 3$.

10. Pencampuran II

Proses pencampuran II berupa pencampuran konsetrasi pemanis terpilih.

11. Pengemasan

Proses pengemasan merupakan proses selanjutnya dimana produk di kemas dengan botol kaca yang sudah di sterilisasi dahulu.

\section{Hasil dan Pembahasan \\ Penelitian Pendahuluan}

Penelitian pendahuluan yang dilakukan pada penelitian ini yaitu menentukan konsentrasi pemanis terpilih sebagai acuan yang akan digunakan pada penelitian utama. Konsentrasi pemanis yang digunakan adalah $1 \%, 2 \%, 3 \%$, dan $4 \%$. Parameter yang digunakan untuk menentukan konsentrasi pemanis terpilih yaitu dengan menggunakan uji organoleptik metode uji hedonik pada minuman fungsional sari buah mengkudu dan filtrat daun rambutan dimana atribut yang diuji antara lain yaitu atribut after taste manis, rasa, aroma dan after taste pahit. Nilai rata-rata dari semua atribut dijumlahkan dan jumlah rata-rata semua atribut yang terbesar yang dipilih. Selain itu pada penelitian pendahuluan dilakukan pula analisis kimia yaitu uji kadar Tanin terhadap daun rambutan, uji aktivitas antioksidan terhadap buah mengkudu, dan uji aktivitas antioksidan terhadap sari buah mengkudu pasca fermentasi. Tujuan dilakukannya analisis kimia pada penelitian pendahuluan yaitu untuk mengetahui adanya 
penurunan atau penaikan kadar Tanin dan aktivitas antioksidan terhadap produk minuman fungsional.

\section{Uji Organoleptik}

Uji organoleptik pada penelitian pendahuluan dilakukan untuk menentukan konsentrasi pemanis terpilih yang akan digunakan pada penelitian utama.

\section{After Taste Manis}

Berdasarkan hasil analisis variansi (ANAVA) terhadap after taste manis minuman fungsional menunjukkan bahwa penambahan pemanis gula stevia berpengaruh terhadap after taste manis minuman fungsional. Pengaruh penambahan pemanis gula stevia dapat dilihat pada tabel.

Tabel 1. Pengaruh Penambahan pemanis gula stevia terhadap after taste manis minuman fungsional

\begin{tabular}{|c|c|c|}
\hline $\begin{array}{c}\text { Penambahan } \\
\text { Pemanis }\end{array}$ & $\begin{array}{c}\text { Nilai Rata }- \\
\text { rata Perlakuan }\end{array}$ & $\begin{array}{c}\text { Taraf } \\
\text { Nyata 5\% }\end{array}$ \\
\hline $\mathrm{p} 1(1 \%)$ & 4.225 & $\mathrm{a}$ \\
\hline $\mathrm{p} 4(4 \%)$ & 4.2425 & $\mathrm{a}$ \\
\hline $\mathrm{p} 2(2 \%)$ & 4.375 & $\mathrm{~b}$ \\
\hline $\mathrm{p} 3(3 \%)$ & 4.6175 & $\mathrm{c}$ \\
\hline
\end{tabular}

Hasil pengujian organoleptik terhadap atribut after taste manis penambahan pemanis menunjukkan perlakuan p3 (penambahan pemanis sebanyak 3\%) lebih disukai daripada perlakuan lainnya, karena perlakuan p3 memperoleh nilai rata-rata tertinggi yaitu 4.6175 nilai yang mendekati 5 atau memiliki nilai hedonik menurut penilaian panelis yang berarti suka. Nilai rata-rata terendah untuk atribut after taste manis adalah perlakuan $\mathrm{p}_{1}$ (penambahan pemanis sebanyak 1\%) dengan nilai rata-rata sebesar 4,225 nilai yang mendekati 4 atau memiliki nilai hedonik menurut penilaian panelis yang berarti agak suka. Hal ini menunjukkan bahwa penambahan pemanis sebanyak $3 \%$ menimbulkan after taste manis yang disukai panelis.

\section{Rasa}

Berdasarkan hasil analisis variansi (ANAVA) terhadap rasa minuman fungsional menunjukkan bahwa penambahan pemanis gula stevia tidak berpengaruh terhadap rasa minuman fungsional.

\section{Aroma}

Berdasarkan hasil analisis variansi (ANAVA) terhadap aroma minuman fungsional menunjukkan bahwa penambahan pemanis gula stevia berpengaruh terhadap aroma minuman fungsional. Pengaruh penambahan pemanis gula stevia dapat dilihat pada tabel.
Tabel 2. Pengaruh Penambahan pemanis gula stevia terhadap aroma minuman fungsional

\begin{tabular}{|l|l|l|}
\hline $\begin{array}{l}\text { Penambahan } \\
\text { Pemanis }\end{array}$ & $\begin{array}{l}\text { Nilai Rata }- \\
\text { rata Perlakuan }\end{array}$ & $\begin{array}{l}\text { Taraf } \\
\text { Nyata 5\% }\end{array}$ \\
\hline P2 (2\%) & 2.71 & $\mathrm{a}$ \\
\hline P4 (4\%) & 2.85 & $\mathrm{ab}$ \\
\hline P1 (1\%) & 2.8575 & $\mathrm{~b}$ \\
\hline P3 (3\%) & 2.885 & $\mathrm{~b}$ \\
\hline
\end{tabular}

Hasil pengujian organoleptik terhadap atribut aroma penambahan pemanis menunjukkan perlakuan $\mathrm{p} 3$ (penambahan pemanis sebanyak 3\%) lebih disukai daripada perlakuan lainnya, karena perlakuan p3 memperoleh nilai rata-rata tertinggi yaitu 2.885 nilai yang mendekati 3 atau memiliki nilai hedonik menurut penilaian panelis yang berarti agak tidak suka. Nilai rata-rata terendah untuk atribut aroma adalah perlakuan p2 (penambahan pemanis sebanyak 2\%) dengan nilai rata-rata sebesar 2.71 nilai yang mendekati 3 atau memiliki nilai hedonik menurut penilaian panelis yang berarti agak tidak suka. Hal ini menunjukkan bahwa penambahan pemanis sebanyak 3\% menimbulkan aroma yang agak tidak disukai panelis. Perbedaan nilai yang tidak begitu signifikan dapat diakibatkan karena gula stevia tidak memiliki aroma yang khas sehingga panelis sulit untuk membedakannya.

Hal ini mungkin disebabkan karena aroma sangat sukar untuk diukur sehingga menimbukan pendapat yang berlainan dalam menilai kualitas. Perbedaan pendapat yaitu perbedaan sensitifitas dalam merasa dan mencium. Meskipun dapat mendeteksi, tiap orang mempunyai kesukaan yang berlainan (Wijaya, 2002).

\section{After Taste Pahit}

Berdasarkan hasil analisis variansi (ANAVA) terhadap after taste pahit minuman fungsional menunjukkan bahwa penambahan pemanis gula stevia berpengaruh terhadap after taste pahit minuman fungsional. Pengaruh penambahan pemanis gula stevia dapat dilihat pada tabel.

Tabel 3. Pengaruh Penambahan pemanis gula stevia terhadap after taste pahit minuman fungsional

\begin{tabular}{|c|c|c|}
\hline $\begin{array}{c}\text { Penambahan } \\
\text { Pemanis }\end{array}$ & $\begin{array}{c}\text { Nilai Rata-rata } \\
\text { Perlakuan }\end{array}$ & $\begin{array}{c}\text { Taraf } \\
\text { Nyata 5\% }\end{array}$ \\
\hline $\mathrm{p} 4(4 \%)$ & 3.3250 & $\mathrm{a}$ \\
\hline $\mathrm{p} 1(1 \%)$ & 3.3925 & $\mathrm{a}$ \\
\hline $\mathrm{p} 2(3 \%)$ & 3.5575 & $\mathrm{~b}$ \\
\hline $\mathrm{p} 3(2 \%)$ & 3.5650 & $\mathrm{~b}$ \\
\hline
\end{tabular}

Hasil pengujian organoleptik terhadap atribut after taste pahit penambahan pemanis menunjukkan perlakuan p3 (penambahan pemanis sebanyak 3\%) lebih 
disukai daripada perlakuan lainnya, karena perlakuan p3 memperoleh nilai rata-rata tertinggi yaitu 3,5650 nilai yang mendekati 4 atau memiliki nilai hedonik menurut penilaian panelis yang berarti agak suka. Nilai rata-rata terendah untuk atribut aroma adalah perlakuan $\mathrm{p} 4$ (penambahan pemanis sebanyak 4\%) dengan nilai ratarata sebesar 3.3250 nilai yang mendekati 3 atau memiliki nilai hedonik menurut penilaian panelis yang berarti agak tidak suka. Hal ini menunjukkan bahwa penambahan pemanis sebanyak $3 \%$ menimbulkan after taste pahit yang agak disukai panelis.

\section{Uji Kadar Tanin}

Tujuan dari analisis bahan baku ini adalah untuk mengetahui kandungan Tanin yang ada pada daun rambutan, kemudian akan menjadi acuan umum dari analisis pada penelitian utama. Berdasarkan analisis bahan baku didapat kadar Tanin pada daun rambutan adalah $0,0488 \%$.

\section{Uji Aktivitas Antioksidan}

Hasil penelitian pendahuluan aktivitas antioksidan yaitu didapatkan hasil bahwa aktivitas antioksidan pada buah mengkudu dengan nilai IC50 yaitu 1979,246 ppm. Sedangkan nilai IC50 pada sari buah mengkudu pasca fermentasi adalah 1123,1076 ppm. Berikut ini adalah tabel tingkat kekuatan antioksidan :

Tabel 4. Tingkat Kekuatan Antioksidan dengan Metode DPPH

\begin{tabular}{|c|c|}
\hline Intensitas & Nilai $\mathbf{I C}_{\mathbf{5 0}}(\mathbf{p p m})$ \\
\hline Sangat Kuat & $<50$ \\
\hline Kuat & $50-100$ \\
\hline Sedang & $101-150$ \\
\hline Lemah & $>150$ \\
\hline
\end{tabular}

Sumber : Afriyanto, (2006)

Hasil aktivitas antioksidan menunjukkan bahwa antiosidan dari bahan baku dan sari buah mengkudu pasca fermentasi termasuk ke dalam antioksidan golongan lemah karena memiliki nilai IC50 lebih besar dari $150 \mathrm{ppm}$.

\section{Penelitian Utama}

Penelitian yang dilakukan pada penelitian utama yaitu menentukan adanya pengaruh perbandingan konsentrasi sari buah mengkudu dan filtrat daun rambutan, yang terdiri dari 6 taraf dengan 4 kali pengulangan. Parameter yang digunakan untuk menentukan perbandingan konsentrasi yaitu dengan menggunakan uji organoleptik metode uji hedonik pada minuman fungsional sari buah mengkudu dan filtrat daun rambutan dimana atribut yang diuji antara lain yaitu atribut warna, rasa, aroma dan after taste.

Selain itu pada penelitian utama dilakukan pula analisis kimia yaitu analisis kadar vitamin C, uji kadar Tanin terhadap produk terpilih, dan uji aktivitas antioksidan terhadap produk terpilih, Tujuan dilakukannya analisis kimia pada penelitian utama yaitu untuk mengetahui adanya penurunan atau penaikan kadar Tanin dan aktivitas antioksidan, serta kadar vitamin $\mathrm{C}$ terhadap produk minuman fungsional.

\section{Uji Organoleptik}

Uji organoleptik pada penelitian utama dilakukan untuk mengetahui adanya pengaruh dari perbandingan konsentrasi antara sari buah mengkudu dan filtrat daun rambutan terhadap warna, rasa, aroma dan after taste manis pada minuman fungsional sari buah mengkudu dan filtrat daun rambutan.

\section{Warna}

Berdasarkan hasil analisis variansi (ANAVA) terhadap warna minuman fungsional menunjukkan bahwa perbandingan antara sari buah mengkudu dan filtrat daun rambutan berpengaruh terhadap karakteristik warna minuman fungsional. Pengaruh perbandingan sari buah mengkudu dan filtrat daun rambutan terhadap warna minuman fungsional dapat dilihat pada Tabel 5.

Tabel 5. Perbandingan Sari Buah Mengkudu dan Filtrat Daun Rambutan Terhadap karakteristik Warna Minuman Fungsional

\begin{tabular}{|l|l|l|}
\hline $\begin{array}{l}\text { Perbandingan } \\
\text { Sari Buah Mengkudu : Filtrat } \\
\text { Daun Rambutan }\end{array}$ & $\begin{array}{l}\text { Rata } \\
\text { rata } \\
\text { perlakuan }\end{array}$ & $\begin{array}{l}\text { Taraf } \\
5 \%\end{array}$ \\
\hline $\mathrm{m} 1(4: 1)$ & 2,64 & $\mathrm{a}$ \\
\hline $\mathrm{m} 2(3: 1)$ & 3,06 & $\mathrm{~b}$ \\
\hline $\mathrm{m} 3(2: 1)$ & 3,53 & $\mathrm{c}$ \\
\hline $\mathrm{m} 4(1: 1)$ & 3,28 & $\mathrm{~d}$ \\
\hline $\mathrm{m} 5(1: 2)$ & 3,79 & $\mathrm{e}$ \\
\hline $\mathrm{m} 6(1: 3)$ & 4,22 & $\mathrm{~F}$ \\
\hline
\end{tabular}
organoleptik terhadap atribut warna minuman fungsional menunjukkan bahwa perlakuan m6 (perbandingan sari buah mengkudu dengan filtrat daun rambutan 1:3) lebih disukai daripada perlakuan lainnya, karena perlakuan m6 memperoleh nilai rata-rata tertinggi yaitu 4,22 atau memiliki nilai hedonik menurut penilaian panelis yang berarti agak suka. Nilai rata-rata terendah untuk rasa minuman fungsional adalah perlakuan $\mathrm{m} 1$ (perbandingan sari buah mengkudu dan filtrat daun rambutan 4:1) dengan nilai rata-rata sebesar 2,64 nilai yang mendekati 3 atau memiliki nilai hedonik menurut penilaian panelis yang berarti agak tidak suka. Hal ini menunjukkan bahwa semakin banyak perbandingan mengkudu yang ditambahkan maka warna minuman fungsional tidak disukai oleh panelis.

\section{Rasa}

Berdasarkan hasil analisis variansi (ANAVA) terhadap rasa minuman fungsional menunjukkan bahwa perbandingan antara sari buah mengkudu dan filtrat daun rambutan berpengaruh terhadap karakteristik rasa minuman fungsional. Pengaruh perbandingan sari buah mengkudu dan filtrat daun rambutan terhadap rasa minuman fungsional dapat dilihat pada Tabel 6. 
Tabel 6. Perbandingan Sari Buah Mengkudu dan Filtrat Daun Rambutan Terhadap Karakteristik Rasa Minuman Fungsional

\begin{tabular}{|l|l|l|}
\hline $\begin{array}{l}\text { Perbandingan } \\
\text { Sari Buah Mengkudu : Filtrat } \\
\text { Daun Rambutan }\end{array}$ & $\begin{array}{l}\text { Rata } \\
\text { rata } \\
\text { perlakuan }\end{array}$ & $\begin{array}{l}\text { Taraf } \\
5 \%\end{array}$ \\
\hline $\mathrm{m} 2(3: 1)$ & 2,998 & $\mathrm{a}$ \\
\hline $\mathrm{m} 1(4: 1)$ & 3,025 & $\mathrm{a}$ \\
\hline $\mathrm{m} 4(1: 1)$ & 3,20 & $\mathrm{~b}$ \\
\hline $\mathrm{m} 5(1: 2)$ & 3,208 & $\mathrm{~b}$ \\
\hline $\mathrm{m} 3(2: 1)$ & 3,265 & $\mathrm{~b}$ \\
\hline $\mathrm{m} 6(1: 3)$ & 3,408 & $\mathrm{c}$ \\
\hline
\end{tabular}

Berdasarkan tabel 6. hasil pengujian organoleptik terhadap atribut rasa minuman fungsional menunjukkan bahwa perlakuan m6 (perbandingan sari buah mengkudu dengan filtrat daun rambutan 1:3) lebih disukai daripada perlakuan lainnya, karena perlakuan m6 memperoleh nilai rata-rata tertinggi yaitu 3,408 atau memiliki nilai hedonik menurut penilaian panelis yang berarti agak tidak suka. Nilai rata-rata terendah untuk rasa minuman fungsional adalah perlakuan m2(perbandingan sari buah mengkudu dan filtrat daun rambutan 3:1) dengan nilai rata-rata sebesar 2,998 nilai yang mendekati 3 atau memiliki nilai hedonik menurut penilaian panelis yang berarti agak tidak suka. Hal ini menunjukkan bahwa semakin banyak perbandingan mengkudu yang ditambahkan maka rasa minuman fungsional tidak disukai oleh panelis.

\section{Aroma}

Berdasarkan hasil analisis variansi (ANAVA) terhadap aroma minuman fungsional menunjukkan bahwa perbandingan antara sari buah mengkudu dengan filtrat daun rambutan berpengaruh terhadap karakteristik aroma minuman fungsional. Pengaruh perbandingan sari buah mengkudu dengan filtrat daun rambutan pada atribut warna dapat dilihat pada Tabel 7.

Tabel 7. Perbandingan Sari Buah Mengkudu dan Filtrat Daun Rambutan Terhadap karakteristik Aroma Minuman Fungsional

\begin{tabular}{|c|c|c|}
\hline $\begin{array}{c}\text { Perbandingan } \\
\text { Sari Buah Mengkudu : } \\
\text { Filtrat Daun Rambutan }\end{array}$ & $\begin{array}{c}\text { Rata }- \text { rata } \\
\text { perlakuan }\end{array}$ & $\begin{array}{c}\text { Taraf } \\
\text { nyata }\end{array}$ \\
\hline $\mathrm{m} 1(4: 1)$ & 2,19 & $\mathrm{~A}$ \\
\hline $\mathrm{m} 2(3: 1)$ & 2,44 & $\mathrm{~B}$ \\
\hline $\mathrm{m} 3(2: 1)$ & 2,79 & $\mathrm{C}$ \\
\hline $\mathrm{m} 4(1: 1)$ & 3,13 & $\mathrm{D}$ \\
\hline $\mathrm{m} 5(1: 2)$ & 3,64 & $\mathrm{E}$ \\
\hline $\mathrm{m} 6(1: 3)$ & 3,95 & $\mathrm{~F}$ \\
\hline
\end{tabular}

Berdasarkan tabel 7. hasil pengujian organoleptik terhadap atribut aroma minuman fungsional menunjukkan bahwa perlakuan m6 (perbandingan sari buah mengkudu dengan filtrat daun rambutan 1:3) lebih disukai daripada perlakuan lainnya, karena perlakuan m6 memperoleh nilai rata-rata tertinggi yaitu 3,95 nilai yang mendekati 4 atau memiliki nilai hedonik menurut penilaian panelis yang berarti agak suka. Nilai rata-rata terendah untuk rasa minuman fungsional adalah perlakuan $\mathrm{m} 1$ (perbandingan sari buah mengkudu dan filtrat daun rambutan 4:1) dengan nilai rata-rata sebesar 2,19 nilai yang mendekati 2 yang berarti tidak suka. Hal ini menunjukkan bahwa semakin banyak perbandingan mengkudu yang ditambahkan maka warna minuman fungsional tidak disukai oleh panelis.

\section{After Taste}

Berdasarkan hasil analisis variansi (ANAVA) terhadap after taste minuman fungsional menunjukkan bahwa perbandingan antara sari buah mengkudu dengan filtrat daun rambutan tidak berpengaruh terhadap karakteristik after taste minuman fungsional. Hal ini dapat disebabkan karena penambahan konsentrasi gula stevia tidak terlalu banyak yaitu 3\% sehingga tidak menimbulkan kesan.

\section{Produk Terpilih}

Produk terpilih pada penelitian utama ditentukan dengan analisis statistika metode hedonik berdasarkan respon organoleptik. Hasil analisis statistik metode hedonik penentuan produk terpilih penambahan pemanis dapat dilihat pada Tabel 8.

Tabel 8. Hasil Analisis Statistik Metode Hedonik Penentuan Pemanis Terpilih

\begin{tabular}{|c|c|c|c|c|}
\hline \multirow{2}{*}{$\begin{array}{c}\text { Kode } \\
\text { Sampel }\end{array}$} & \multicolumn{4}{|c|}{ Respon Organoleptik } \\
\cline { 2 - 5 } & Warna & Rasa & Aroma & $\begin{array}{c}\text { After } \\
\text { Taste }\end{array}$ \\
\hline $\mathrm{m} 1(4: 1)$ & $2.64 \mathrm{a}$ & $3.025 \mathrm{a}$ & $2.19 \mathrm{a}$ & $3.01 \mathrm{a}$ \\
\hline $\mathrm{m} 2(3: 1)$ & $3.06 \mathrm{~b}$ & $2.998 \mathrm{a}$ & $2.44 \mathrm{~b}$ & $3.39 \mathrm{a}$ \\
\hline $\mathrm{m} 3(2: 1)$ & $3.53 \mathrm{c}$ & $3.265 \mathrm{~b}$ & $2.79 \mathrm{c}$ & $3.33 \mathrm{a}$ \\
\hline $\mathrm{m} 4(1: 1)$ & $3.28 \mathrm{~d}$ & $3.20 \mathrm{~b}$ & $3.13 \mathrm{~d}$ & $3.17 \mathrm{a}$ \\
\hline $\mathrm{m} 5(1: 2)$ & $3.79 \mathrm{e}$ & $3.208 \mathrm{~b}$ & $3.64 \mathrm{e}$ & $3.19 \mathrm{a}$ \\
\hline $\mathbf{m 6}(\mathbf{1 : 3})$ & $\mathbf{4 . 2 2} \mathbf{f}$ & $\mathbf{3 . 4 0 8} \mathbf{c}$ & $\mathbf{3 . 9 5} \mathbf{f}$ & $\mathbf{3 . 3 2} \mathbf{a}$ \\
\hline
\end{tabular}

Berdasarkan data hasil analisis, maka produk terpilih pada penelitian utama adalah sampel m6 dengan perbandingan sari buah mengkudu dan filtrat daun rambutan yaitu $3: 1$.

\section{Analisis kadar vitamin C}

Berdasarkan hasil analisis variansi (ANAVA) terhadap analisis kadar vitamin $\mathrm{C}$ minuman fungsional menunjukkan bahwa perbandingan antara sari buah mengkudu dengan filtrat daun rambutan tidak berpengaruh terhadap kandungan vitamin $\mathrm{C}$ minuman fungsional. Hal ini dapat disebabkan karena konsentrasi perbandingan sari buah mengkudu dan filtrat daun rambutan tidak memiliki rentang yang terlalu signifikan.

Vitamin C merupakan suatu asam organik yang berbentuk kristal putih dan terasa asam dan tidak berbau. Di dalam larutan vitamin $\mathrm{C}$ mudah rusak akibat teroksidasi oleh oksigen dan udara. Vitamin ini menjadi 
lebih stabil nila dalam bentuk kristal kering (Adra, 2011).

\section{Analisis Aktivitas Antioksidan Produk Terpilih}

Hasil penelitian utama aktivitas antioksidan yaitu didapatkan hasil bahwa aktivitas antioksidan pada produk terbaik dengan nilai $\mathrm{IC}_{50}$ yaitu $1523,308 \mathrm{ppm}$. Sedangkan nilai aktivitas antioksidan pada buah mengkudu dengan nilai $\mathrm{IC}_{50}$ yaitu 1979,246 ppm dan nilai IC $_{50}$ pada sari buah mengkudu pasca fermentasi adalah 1123,1076 ppm.

Tabel 24. Tingkat Kekuatan Antioksidan dengan Metode DPPH

\begin{tabular}{|c|c|}
\hline Intensitas & ${\text { Nilai } \mathbf{I C}_{\mathbf{5 0}}(\mathbf{p p m})} \mathbf{< 5 0}$ \\
\hline Sangat Kuat & $50-100$ \\
\hline Kuat & $101-150$ \\
\hline Sedang & $>150$ \\
\hline Lemah &
\end{tabular}

Sumber : Ariyanto, (2006).

Hasil aktivitas antioksidan menunjukkan bahwa antioksidan dari bahan baku, sari buah mengkudu pasca fermentasi dan produk terpilih termasuk ke dalam antioksidan golongan lemah karena memiliki nilai $\mathrm{IC}_{50}$ lebih besar dari 150 ppm.

\section{Analisis Aktivitas Antioksidan}

Pada penelitian utama dilakukan analisis kimia kadar Tanin dengan tujuan untuk mengetahui adanya pengaruh perlakuan terhadap kadar Tanin pada produk minuman fungsional sari buah mengkudu dan filtrat daun rambutan. Berdasarkan analisis pada produk terpilih didapat kadar Tanin pada daun produk minuman fungsional adalah $0,0657 \%$ sedangkan hasil analisis bahan baku didapat kadar Tanin pada daun rambutan adalah $0,0347 \%$.

Hasil tersebut menunjukkan adanya pengaruh perlakuan terhadap kadar Tanin pada produk. Pengaruh perlakuan tersebut dapat disebabkan oleh adanya penambahan sari buah mengkudu, sehingga kadar Tanin pada produk dapat meningkat.

Berdasarkan penelitian yang telah dilakukan, maka diperoleh kesimpulan bahwa perbandingan sari buah mengkudu dan filtrat daun rambutan berpengaruh terhadap karakteristik minuman fungsional meliputi respon organoleptik yaitu warna, aroma, rasa dan after taste minuman fungsional. Namun tidak berpengaruh terhadap kandungan vitamin $\mathrm{C}$.

\section{Daftar Pustaka}

1. Andriyani. 2010. Penetapan Kadar Tanin Daun Rambutan (Nephelium lappaceum L) Secara Spektrofotometri Ultraviolet Visibel. Universitas Muhammadiyah Purwokerto, Jawa Tengah.

2. Badan Pengawasan Obat dan Makanan. 2001. Kajian Proses Standarisasi Produk Pangan Fungsional di Badan Pengawasan Obat dan Makanan. Lokakarya Kajian Penyusunan Standar
Pangan Fungsional. Badan Pengawasan Obat dan Makanan, Jakarta.

3. Dalimartha, S. 2007. Atlas Tumbuhan Obat Indonesia, Jakarta.

4. Gaspersz, V. 2006. Teknik Analisis Dalam Penelitian Percobaan. Penerbit : Tarsito. Bandung

5. Harborne, S.B. 1987. Metode Fitokimia. Bandung: ITB P: 21, 71,102-104

6. Muchtadi, Deddy. 2012. Pangan Fungsional \& Senyawa Bioaktif. Penerbit : Alfabeta, Bandung

7. Pohan, H.G. dan N.T. Antara. 2001. Pengaruh Penambahan Madu dan Asam Sitrat Terhadap Karakteristik Minuman Fungsional dari Sari Buah Mengkudu. Forum Komunikasi IHP (4) : 1120

8. Septiatin, Entin. 2009. Apotek Hidup dari Tanaman Buah. Penerbit : CV. Yrama Widya, Bandung.

9. Solomon, N. 1998. Nature's Amazing Healer. Noni. Woodland Publ. Pleasant Grove, Utah, USA.

10. Tanggara, N.,L.M. Ekawati, P dan F. Sinung, P. 2013. Kualitas Sirup Goji Berry Dengan Kombinasi Kadar Angkak dan Suhu Perebusan: $1-15$.

11. Widjanarko. S.B. 1996. Perubahan Sifat FisikoKimia dan Sensoris Sirup Pisang dari Tiga Varietas Pisang yang Berbeda Akibat Penggunaan Na-CMC Pada Konsentrasi yang Berbeda. Jurnal Universitas Brawijaya. 8(2) : 105114.

12. Winarti, Christina. 2005. Peluang Pengembangan Minuman Fungsional dari Buah Mengkudu (Morinda citrifolia L.). Balai Besar Penelitian dan Pengembangan Pascapanen Pertanian, Bogor.

13. Winarti, Sri. (2010). Makanan Fungsional. Cetakan Pertama. Graha Ilmu : Yogyakarta. 